\title{
Experimental and Numerical Study of Pressure Intensity in Detachable Joints of D Series Pumps
}

\author{
A.A. Rudenko ${ }^{1} \bullet$ V.M. Zubko ${ }^{2} \bullet$ V.F. Khvorost ${ }^{1} \bullet$ A.A. Lysenko ${ }^{1}$
}

Received: 8 June 2021 / Accepted: 25 October 2021

\begin{abstract}
The object of study is a single-stage double-suction axially split volute casing centrifugal pump.
Background. In the design process of pumps, the problems associated with ensuring the tightness of the axial joint of a pump casing being under the effect of mechanical and temperature loads, are being solved. During the study of axial joint tightness, numerical calculation methods are used to estimate the pressure intensity on the contacting surfaces. A detachable joint under the external load satisfies the criterions of the tightness if the pressure intensity on the sealing surfaces is higher than values of the specific pressure prescribed by regulations. However, inability to experimentally determine the pressure intensity on the contacting surfaces has so far prevented to assess the accuracy of results obtained by the numerical calculation methods.

Objective. In order to verify the numerical results obtained by mathematical models, an experiment was carried out using a special Prescale film that registers the magnitude of the contact pressure on the joint of the specimen model of the flange fragment. Based on the experimental results, an analysis of the pressure intensity distribution was conducted.

Methods. To conduct the experiment, there was developed a method for determining the pressure intensity on the contacting surfaces according to the proposed scheme of the specimen of the flange fragment.

Results. A comparative analysis of the solving results obtained for the contact problem on the finite-element models of the flange fragment and the zone of the pump casing joint in the discharge chamber area showed a good coincidence of the results. Analysis of results obtained experimentally on the specimen of flange fragment and results of the numerical calculation on the flange fragment model also showed a good agreement.

Conclusions. Therefore, results of the calculation of the pressure intensity in the detachable joints on mathematical models have been experimentally confirmed.

Keywords: pressure intensity, tensometric film, main joint, localized zone, specimen of flange fragment, reference zone, numerical simulation of stresses, membrane stresses, experimental simulation, results verification.
\end{abstract}

\section{Introduction}

While creating the pumping equipment there is a necessity of experimental confirmation of the pressure intensity in detachable joints, at which tightness of pump casings working under high pressure is provided. Nowadays only numerical methods of calculation are used for the study of force interaction of elements of casing parts under the effect of mechanical and temperature loads, which allow estimating the pressure intensity of contacting parts

A.A. Rudenko

rudenko@vniiaen.sumy.ua

$\square$ V.M. Zubko

admin@snau.edu.ua

1 Joint-Stock Company “VNIIAEN”, Sumy, Ukraine

${ }^{2}$ Sumy National Agrarian University, Sumy, Ukraine
$[1,2]$. The tightness of detachable joints is estimated according to the analysis results of the pressure intensity. The lack of the possibility to determine experimentally the pressure intensity on the contacting surfaces of the axial casing joint does not allow at the moment to estimate the accuracy of the results obtained by numerical methods of calculation. In order to verify the results based on mathematical models, an experiment was conducted using a Prescale tensometric film to determine the pressure intensity on the axial joint of the pump casing $[3,4]$.

\section{Setting of the Problem}

The object of study is a single-stage double-suction axially split volute casing D series centrifugal pump. The pump is designed to supply water and other liquids. The 
pump casing is a basic assembly unit which consists of cast lower casing half and upper casing half. The choice of the object of study was caused by that volute casing pumps working under high pressure have a main joint with a large contact area.

A typical feature of this pump design is the absence of a seal gasket on the axial joint, so in order to ensure its tightness, higher requirements are established to the quality of machining of the contacting surfaces of the flange joint and the value of the pressure intensity.

Full-scale experiment was conducted to the results verification of the pressure intensity on the flange joint, generated by the mathematical models using numerical methods.

The problem in determining the pressure intensity on the contacting surfaces of the axial joint flanges was realized using ANSYS software [5] on 3D models - the pump casing model and the experimental model including flange fragment of upper casing half and lower casing half, which geometry and loading conditions correspond to the section of the pump axial joint located in the area of pump discharge chamber.

Based on the obtained results, a comparative analysis of the pressure intensity in the local zone on the axial joint of the pump casing and on the joint of the model including flange fragment of upper casing half and lower casing half is carried out.

With the latest advanced technology, Fujifilm has created an ultrafine and supremely strength Prescale film, which can be used to experimentally determine the pressure intensity on the contacting surfaces [3, 4]. It was installed on the joint of the specimen of flange fragment of upper casing half and lower casing half. The pressure applied on the film leaves red imprints on its surface in contact areas. The pressure intensity is determined by the color saturation of the imprints using the pressure diagram or FPD-8010E digital analysis software for Prescale film.

A typical feature of this pump design is the absence of a seal gasket on the axial joint, so in order to ensure its tightness, higher requirements are established to the quality of machining of the contacting surfaces of the flange joint and the value of the pressure intensity.

Full-scale experiment was conducted to the results verification of the pressure intensity on the flange joint, generated by the mathematical models using numerical methods.

The problem in determining the pressure intensity on the contacting surfaces of the axial joint flanges was realized using ANSYS software [5] on 3D models - the pump casing model and the experimental model including flange fragment of upper casing half and lower casing half, which geometry and loading conditions correspond to the section of the pump axial joint located in the area of pump discharge chamber.

Based on the obtained results, a comparative analysis of the pressure intensity in the local zone on the axial joint of the pump casing and on the joint of the model including flange fragment of upper casing half and lower casing half is carried out.

With the latest advanced technology, Fujifilm has created an ultrafine and supremely strength Prescale film, which can be used to experimentally determine the pressure intensity on the contacting surfaces [3, 4]. It was installed on the joint of the specimen of flange fragment of upper casing half and lower casing half. The pressure applied on the film leaves red imprints on its surface in contact areas. The pressure intensity is determined by the color saturation of the imprints using the pressure diagram or FPD-8010E digital analysis software for Prescale film.

\section{Results of Numerical Studies on Mathematical Models}

\section{Generation of Solid and Computational Finite-Element Models}

Determination of the Pressure Intensity on the Contacting Surfaces of Flange Joints Due to the Rated Force of Studs Tightening

Two solid models were constructed by using SolidWorks graphical editor [6] to determine the pressure intensity on the axial joint of the pump casing and on the joint of fragment of flanges of upper casing half and lower casing half. Actual configuration of both parts was taken into account for the modeling.

Figure 1 shows the pump casing model which is assembled of casing parts: lower casing half, upper casing half, shaft seal housings, counter flanges for suction and discharge nozzles and main joint studs.

Figure 2 shows the upper casing half model which is designed of conjugated cladding, stiffening ribs and a studhole flange.

Figure 3 shows the lower casing half model which is designed of conjugated cladding, stiffening ribs, a flange with threaded stud seats and pump feet for fastening to the base plate.

The model of flange fragment of upper casing half and lower casing half, shown in Figure 4, is designed of two coupled parts and a set of fasteners, including a tie bolt, a nut, and a washer. The model of flange fragment corresponds geometrically to the area of the axial joint of the pump casing in the discharge chamber area.

In addition to the alternative model of flange fragment without the film on the main joint, options with samples of the Prescale film placed on the main joint were considered to compare analysis results and assessment of the impact of the film dimension on the contact pressure value. In these cases, two film dimensions were considered - one dimension was $111.5 \times 70 \mathrm{~mm}$, which corresponded to the entire area of the main joint, and the other dimension was $90 \times 70 \mathrm{~mm}$ for the test specimen. 
In the process of solving the contact problem [5], the determination of the pressure intensity on the axial joint of the pump casing and the joint of the flange fragment was realized by the finite-element method [5]. The pressure intensity on the contacting surfaces of the flange fragment, caused by rated force of tightening $Q 0$, was compared with the solution results that were obtained for the localized zone of the axial joint of the pump casing, which is located in the discharge chamber area.

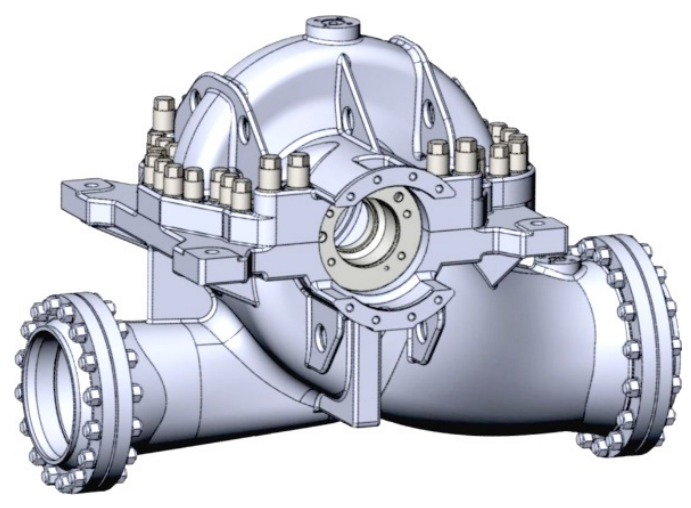

Fig. 1. Solid model of the pump casing

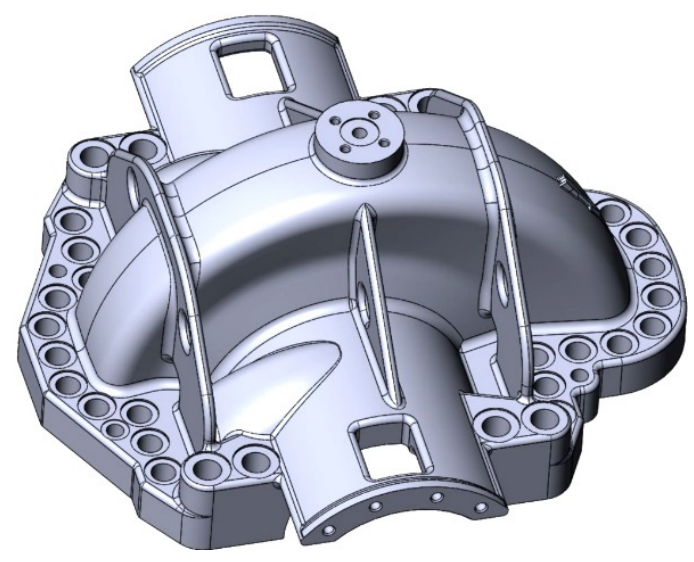

Fig. 2. Solid model of the pump upper casing half

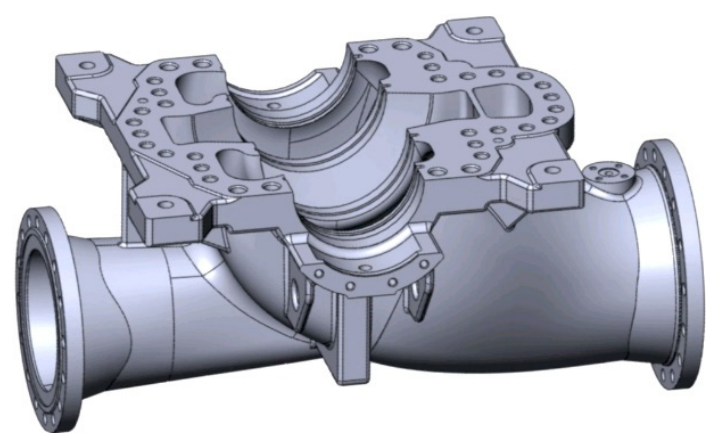

Fig. 3. Solid model of the pump lower casing half

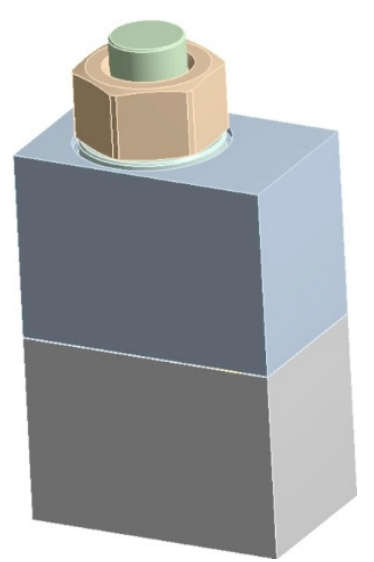

Fig. 4. Solid model of the flange fragment of upper casing half and lower casing half

The solid-state tetrahedral element SOLID187 and the ANSYS mesh generator [5] were used to create finiteelement models.

The elastic interaction of the contacting surfaces was modeled by the TARGE170 and CONTA174 elements being used for forming the contact pairs, such as target and contacting surfaces, respectively. In finite-element models, pairs of possible contacts are recognized by the existence of these elements. The contact problem, the initial data for which are given in Table 1, is solved taking into account the effects associated with friction.

The following figures show analysis results, corresponding to the rated force of studs tightening $\mathrm{QO}$ : the pressure intensity distribution on the axial joint of the pump lower casing half model is shown in Figure 5, and local values of the pressure intensity distribution in reference zones of the area of the axial joint, which is in accordance with the geometry and take-up load of the flange fragment model, are shown in Figure 6.

Figures 7-9 show analysis results of the pressure intensity, corresponding to the rated force of studs tightening $Q 0$ in the reference zones of pressure intensity distribution on the contacting surfaces model of flange fragment of upper casing half and lower casing half for main joint options without the use of film and with Prescale film, having dimensions $111.570 \mathrm{~mm}$ and $9070 \mathrm{~mm}$, respectively.

Comparative analysis of the results obtained from solving the contact problem with the finite-element models under loading by the rated force of studs tightening $Q 0$ is given in Table 2.

Comparison of the analysis results of the contact problem on the finite-element models under loading by the rated force of studs tightening $Q 0$ shows a good coincidence of the results which are listed in the Table 2. The relative accuracy $\delta, \%$, of the pressure distribution on the main joint in the reference zones is rated at 4-18\%. 
Table 1. Initial Data for the Contact Problem

\begin{tabular}{|c|c|c|}
\hline \multirow{2}{*}{$\begin{array}{l}\text { Description } \\
\text { parameter }\end{array}$} & \multicolumn{2}{|c|}{ Parameter value } \\
\hline & pump casing model & flange fragment model \\
\hline Total number of finite elements & $2,538,249$ & 89,989 \\
\hline Total number of nodes & $3,956,513$ & $1,291,356$ \\
\hline $\begin{array}{c}\text { Grip } \\
\text { condition }\end{array}$ & $\begin{array}{l}\text { Zero-point displacements setup } \\
\text { at the points of fastening } \\
\text { the pump to the frame }\end{array}$ & $\begin{array}{l}\text { Zero-point displacements setup } \\
\text { on the lateral surfaces } \\
\text { of the casing flange fragment }\end{array}$ \\
\hline $\begin{array}{l}\text { Materials used } \\
\text { to make the parts }\end{array}$ & $\begin{array}{c}\text { LOWER CASING HALF, } \\
\text { UPPER CASING HALF, } \\
\text { SHAFT SEAL HOUSING - } \\
\text { spheroidal cast iron } \\
\text { BЧ 500-7 acc. to DSTU 3925-99 [7, 8]; } \\
\text { STUD, NUT, WASHER - } \\
\text { Steel 40X acc. to GOST 4543-71 }\end{array}$ & $\begin{array}{c}\text { FLANGE FRAGEMENT } \\
\text { OF LOWER CASING HALF } \\
\text { and UPPER CASING HALF - } \\
\text { Steel } 20 \text { acc. to GOST 1050-2013; } \\
\text { STUD, WASHER - } \\
\text { Steel 40X acc. to GOST 4543-2016; } \\
\text { NUT - Steel } 35 \text { acc. to DSTU 7809:2015 }\end{array}$ \\
\hline $\begin{array}{l}\text { Rated force of tightening } \\
\text { for one stud } \\
\text { (determined according } \\
\text { to the procedure } \\
\text { given in }[9,10] \text { ) }\end{array}$ & $Q 0=0.14663 \mathrm{MN}$ & $Q 0=0.14663 \mathrm{MN}$ \\
\hline $\begin{array}{c}\text { Standard size } \\
\text { and number of studs }\end{array}$ & M36, $N=34$ & M36, $N=1$ \\
\hline $\begin{array}{l}\text { Prescale } \\
\text { Film }\end{array}$ & - & $\begin{array}{l}\text { 1) none film; } \\
\text { 2) presence of type } 3 \text { film } \\
\text { (MS, for medium pressure): } \\
-90 \times 70 \mathrm{~mm} \text {; } \\
-111.5 \times 70 \mathrm{~mm}\end{array}$ \\
\hline
\end{tabular}

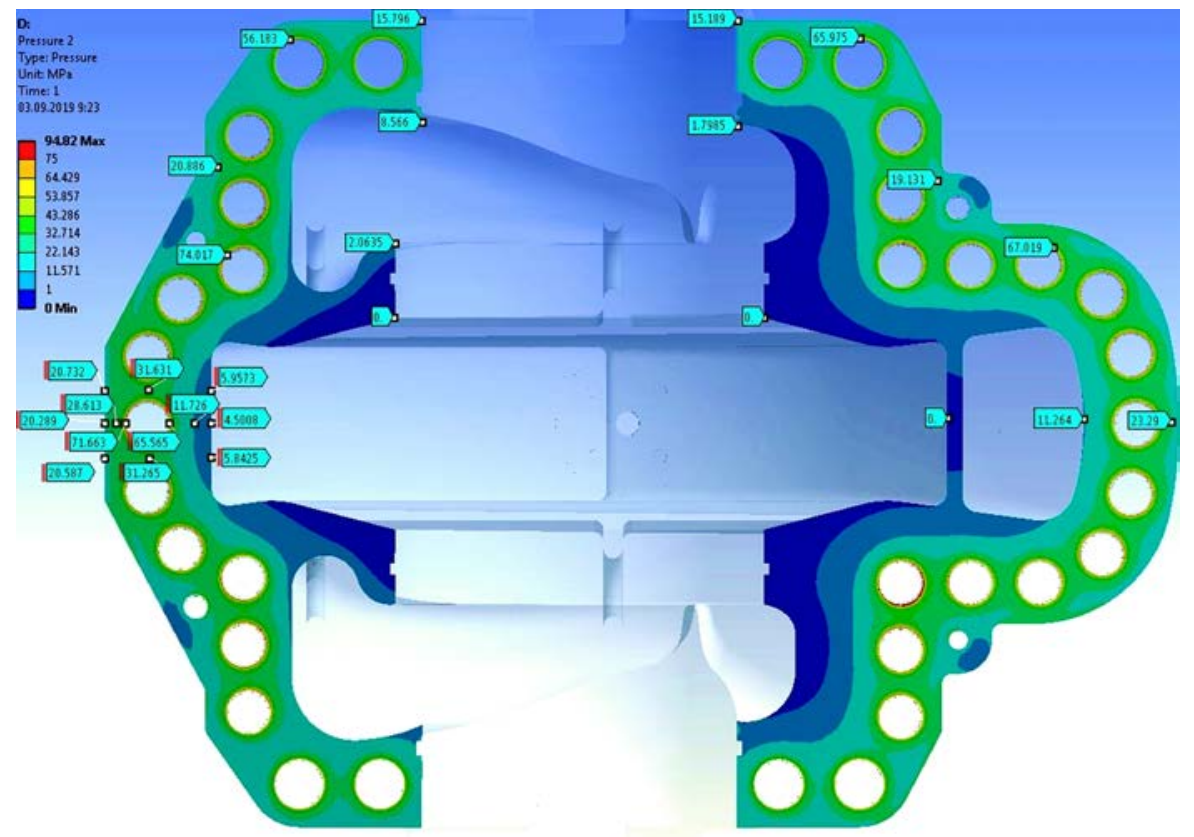

Fig. 5. Distribution of the pressure intensity on the axial joint of the pump lower casing half model, caused by rated force of tightening $Q 0, \mathrm{MPa}$ 


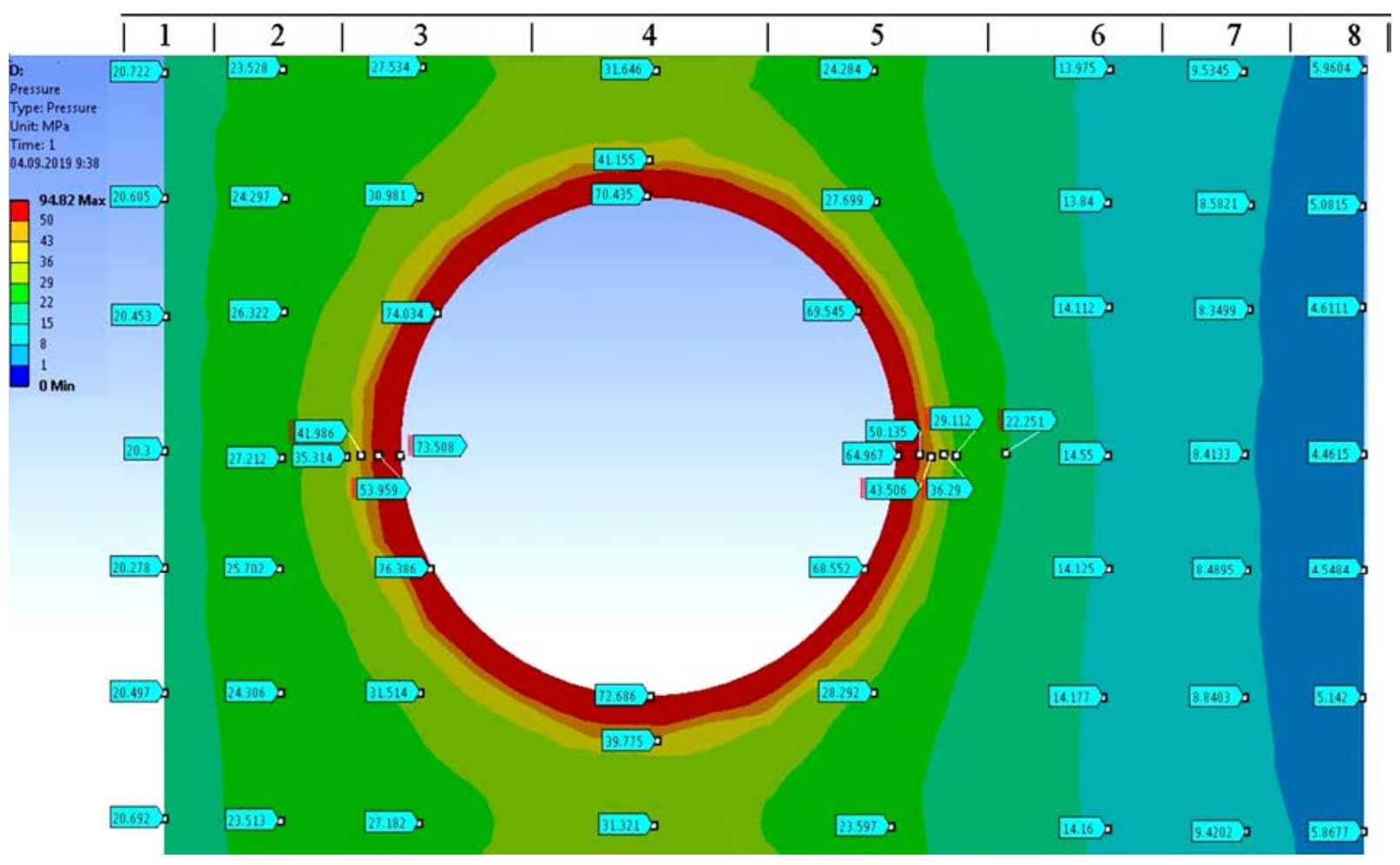

Fig. 6. Distribution of local values of the pressure intensity in reference zones of the area of interest on the axial joint of the lower casing half model, $\mathrm{MPa}$

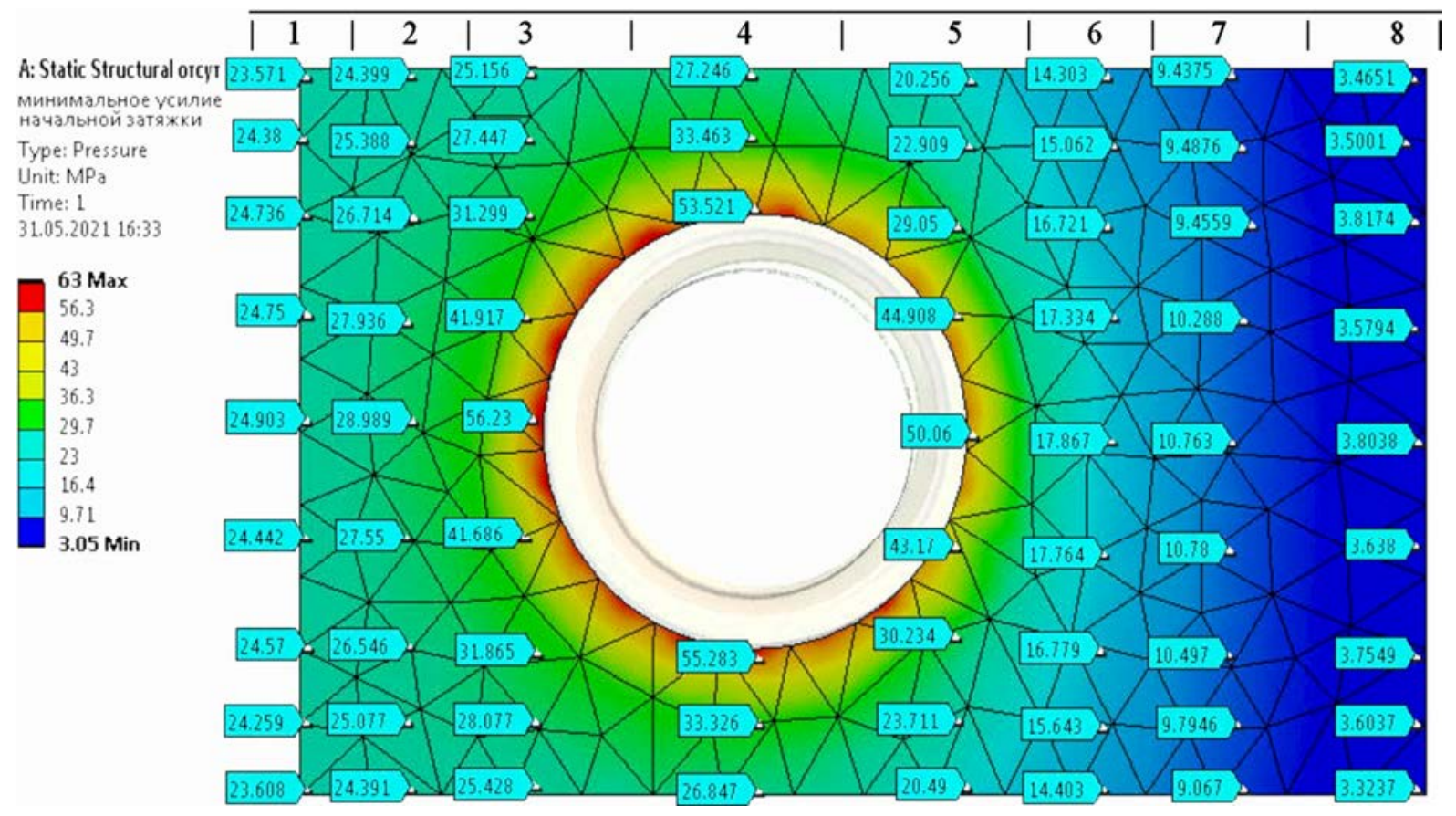

Fig. 7. Distribution of the pressure intensity on the joint of flange fragment model, caused by rated force of tightening Q0 without using the film, MPa 


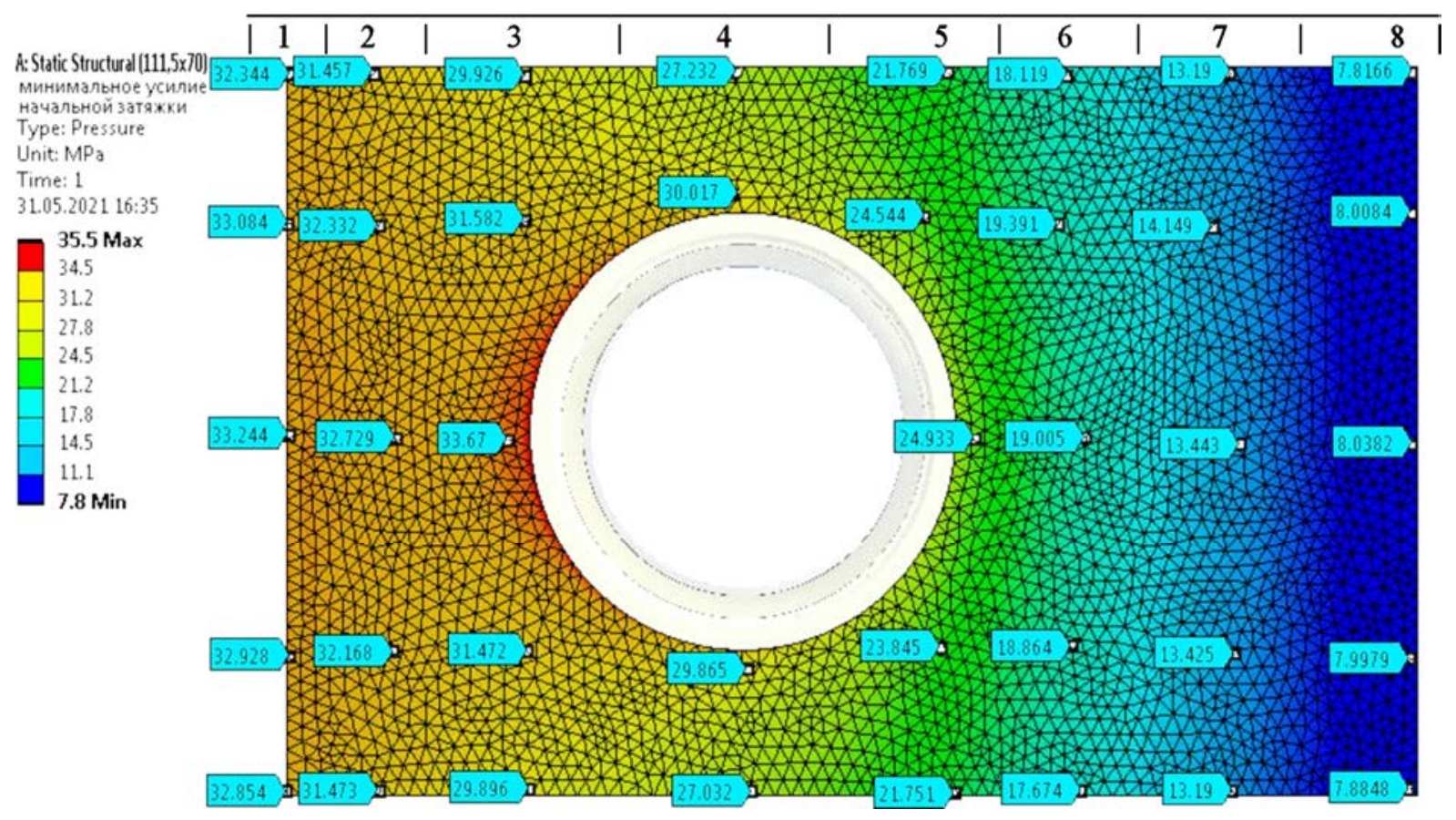

Fig. 8. Distribution of the pressure intensity on the joint of flange fragment model, caused by rated force of tightening Q0 using the film $111.5 \times 70 \mathrm{~mm}$, MPa

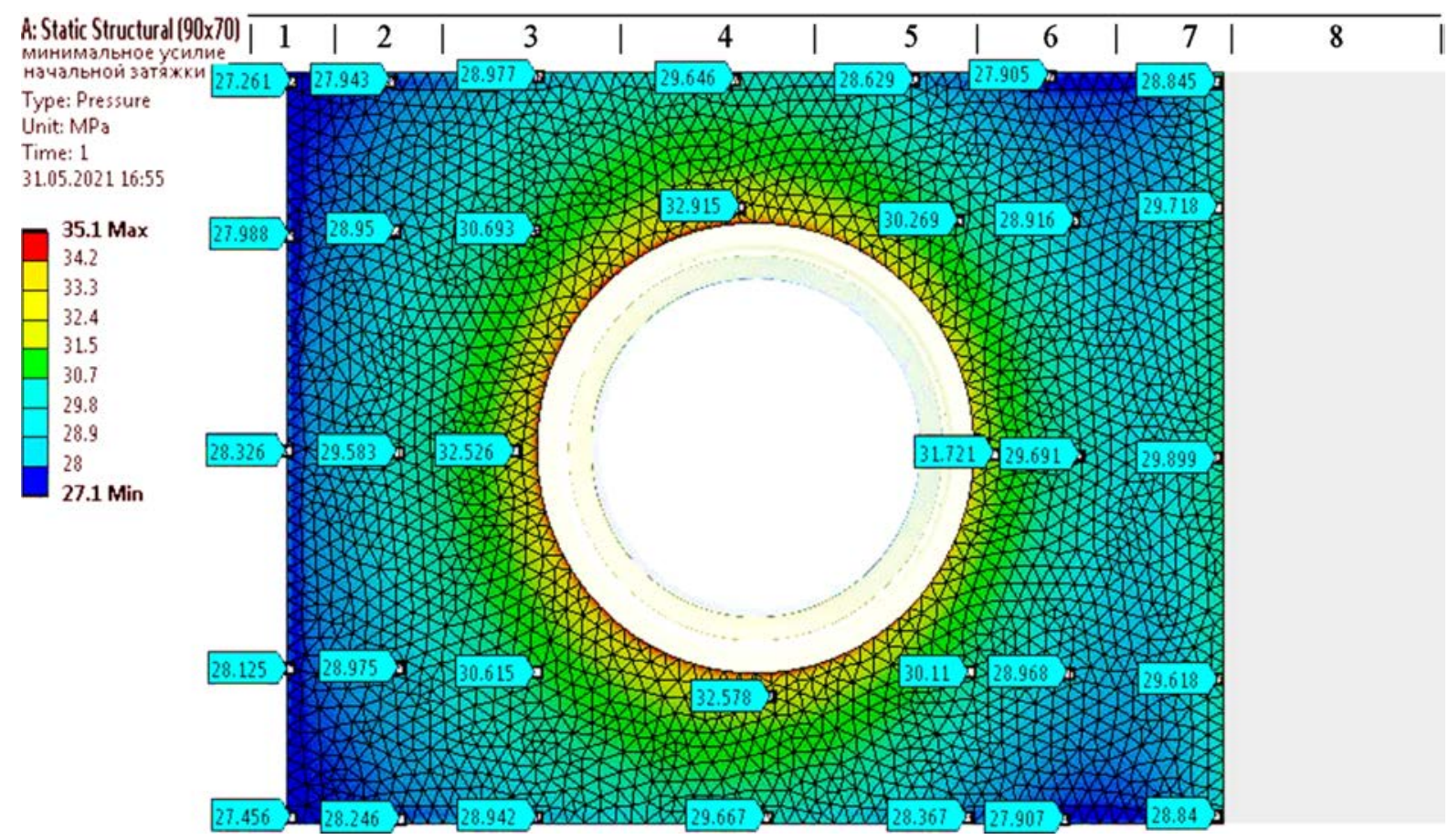

Fig. 9. Distribution of the pressure intensity on the joint of flange fragment model caused by rated force of tightening $Q 0$ using the film $90 \times 70 \mathrm{~mm}, \mathrm{MPa}$ 
Table 2. Comparative Analysis of the Results of Solving the Contact Problem Using Finite-Element Models Under Loading by Analysed Values of Tightening Stress Q0

\begin{tabular}{|c|c|c|c|}
\hline $\begin{array}{c}\text { Reference zones } \\
\text { of pressure intensity distribution } \\
\text { on the joint }\end{array}$ & $\begin{array}{l}\text { Variation interval } \\
\text { of the pressure intensity along } \\
\text { the reference zones on the joint } \\
\text { of the flange fragment model } \\
\text { of upper casing half and lower } \\
\text { casing half (none film), MPa }\end{array}$ & $\begin{array}{c}\text { Variation interval } \\
\text { of the pressure intensity along } \\
\text { reference zones } \\
\text { on the joint } \\
\text { of the pump casing model } \\
\text { (local values on the area } \\
\text { of the axial joint), MPa }\end{array}$ & $\begin{array}{c}\text { Relative accuracy } \delta \\
\text { of analysis results } \\
\text { in the reference zones } \\
\text { on joints of considered mod- } \\
\text { els, } \%\end{array}$ \\
\hline $\begin{array}{l}\text { No. } 1 \text { - zone of the external con- } \\
\text { tour of the flange }\end{array}$ & $23.6-24.9$ & $20.3-20.7$ & 13.9-16.9 \\
\hline $\begin{array}{c}\text { No. } 2 \text { - between the } 1^{\text {st }} \text { and } 3^{\text {rd }} \\
\text { zones }\end{array}$ & $24.4-28.9$ & $23.5-27.2$ & $3.7-5.9$ \\
\hline No. 3 - outer side of the stud hole & $25.4-56.2$ & $27.2-53.9$ & $6.6-4.1$ \\
\hline $\begin{array}{l}\text { No. } 4 \text { - along the perimeter of the } \\
\text { studs }\end{array}$ & $27.2-53.5$ & $31.3-50.0$ & $13.1-6.5$ \\
\hline No. 5 - outer side of the stud hole & $20.2-59.6$ & $23.6-50.1$ & $14.4-15.9$ \\
\hline $\begin{array}{c}\text { No. } 6 \text { - between the } 5^{\text {th }} \text { and } 7^{\text {th }} \\
\text { zones }\end{array}$ & $14.3-17.9$ & $13.8-14.6$ & $3.5-18.4$ \\
\hline No. 7 - between 6th and $8^{\text {th }}$ zones & $9.1-10.8$ & $8.3-9.5$ & $8.8-12.0$ \\
\hline $\begin{array}{l}\text { No. } 8 \text { - zone of the inner contour } \\
\text { of the flange }\end{array}$ & $3.3-3.8$ & $4.5-5.9$ & $26.7-35.6$ \\
\hline
\end{tabular}

\section{Experimental Results of the Pressure Intensity Determination}

Types of Prescale Film Samples Testing Steps

The experiment was performed on a specimen of flange fragment of upper casing half and lower casing half. The geometric model shown in Figure 4 corresponds to the specimen of flange fragment of the axial joint in the area of stud No. 29. The connection diagram and a drawing of the specimen of flange fragment of the main joint are shown in Figure 10.

Table 3. Film Types and Pressure Ranges for its Application

\begin{tabular}{|c|c|c|c|}
\hline \multirow{2}{*}{ No. } & \multirow{2}{*}{$\begin{array}{c}\text { Type of sample } \\
\text { Prescale film }\end{array}$} & \multicolumn{2}{|c|}{ Pressure } \\
\cline { 3 - 4 } & range, MPa & classification \\
\hline 1 & HHS & $130-150$ & ultra high \\
\hline 2 & HS & $50-130$ & high \\
\hline 3 & MS & $10-50$ & medium \\
\hline 4 & LW & $2.5-10$ & low \\
\hline 5 & LLW & $0.5-2.5$ & ultra low \\
\hline 6 & LLLW & $0.2-0.6$ & ultra super-low \\
\hline
\end{tabular}

TOV NVF Diagnostic Tools provided six types of Prescale film samples of a dimension $7090 \mathrm{~mm}$ for use in different pressure ranges to carry out the experiment. Data of the film types and their properties are given in Table 3 and Table 4.

Table 4. Prescale Film Properties and Environmental Parameters

\begin{tabular}{|c|c|c|}
\hline \multirow{2}{*}{ Parameter name } & \multicolumn{2}{|c|}{ Parameter value } \\
\cline { 2 - 3 } & $\begin{array}{c}\text { single-film } \\
\text { option (S) }\end{array}$ & $\begin{array}{c}\text { double-film } \\
\text { option (W) }\end{array}$ \\
\hline Thickness, $\mu \mathrm{m}$ & 100 & $2 \times 100$ \\
\hline Specified temperature, ${ }^{\circ} \mathrm{C}$ & \multicolumn{2}{|c|}{$20 \sim 35$} \\
\hline Specified humidity, \% & \multicolumn{2}{|c|}{$35 \sim 80$} \\
\hline $\begin{array}{c}\text { Accuracy of pressure } \\
\text { measurement, } \% \\
\text { (data obtained by densitometer } \\
\text { at } 23^{\circ} \mathrm{C} \text { and } 65 \% \text { humidity) }\end{array}$ & \multicolumn{2}{|c|}{ \pm 10} \\
\hline
\end{tabular}

Taking into account results of the numerical calculations of the pressure intensity on the joint of the flange fragment model, the 3rd and 4th types of films were chosen for the experiment - a single-layer MS film for medium pressure with a range of 10 to $50 \mathrm{MPa}$ and a double-layer LW film for low pressure with a range of 0.5 to $10 \mathrm{MPa}$ (since there was no single-layer LS film in the kit of the available samples). 


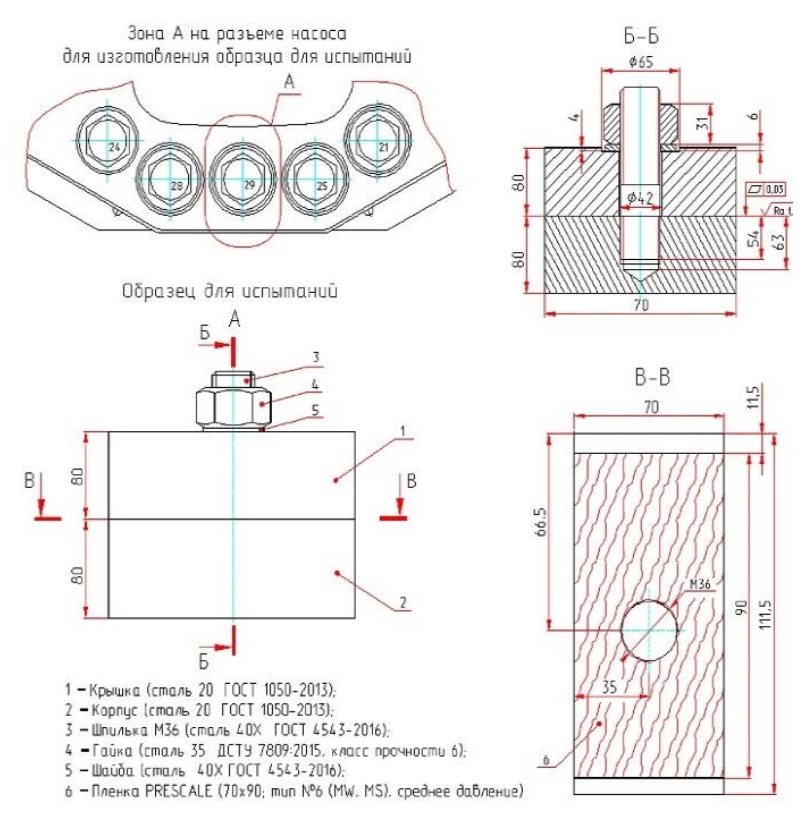

Fig. 10. Connection diagram and specimen of flange fragment of the main joint

Considering the fact that the area of the provided Prescale film samples is less than the contact area of $70 \times 111.5 \mathrm{~mm}$, it was considered to use a combination of film samples: $\mathrm{MS}-70 \times 90 \mathrm{~mm}$ and $\mathrm{LW} \mathrm{A}$, LW C - 7021.5 (Figure 11).

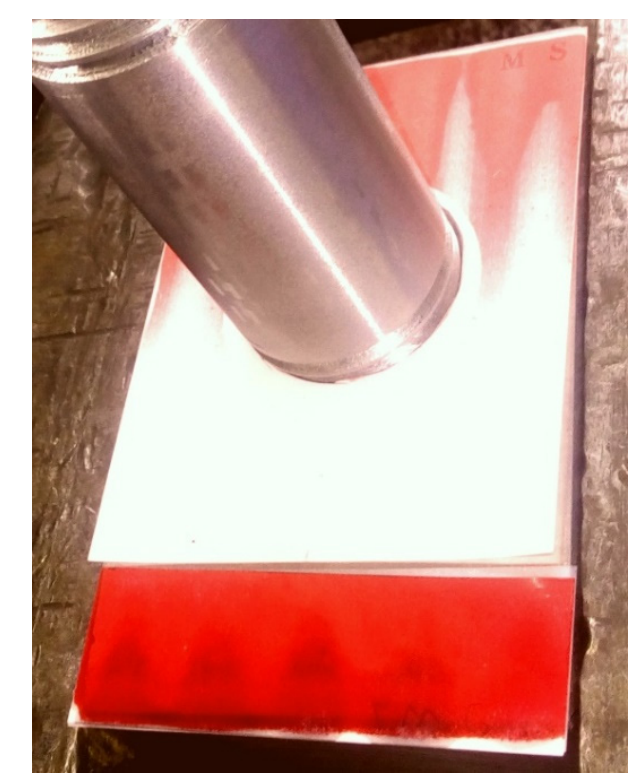

Fig. 11. Test results with two films: single-layer MS (for medium pressure) and double-layer LW (for low pressure)

Test results were not correct due to the difference in thickness of the MS and LW films. Limit pressure-fixing intensity of $10 \mathrm{MPa}$ was achieved over the entire area in the tests with the double-layer LW film. Only the area near the external contour of the detachable connection showed up on the single-layer MS film. Moreover, only in this place the pressure level exceeded the low limit of the pressure fixing $10 \mathrm{MPa}$.

Subsequently, samples of MS $7090 \mathrm{~mm}$ film were used in the experiment.

The experiment was conducted in the following sequence:

1) Before installing Prescale film, the flange joint was assembled and disassembled for removing microroughnesses on the contacting surfaces.

2) Trial tightening of the main joint studs was performed without the film on the main joint to make sure that the applied torque corresponds to the rated force of tightening QO.

3) When the film was installed on the main joint and the model was assembled, the flange joint was tightened with a stud using a dynamic calibrated wrench made at the King Topu factory in accordance with DIN ISO 6789:2017 and ASME B 107.300-2010.

4) Obtained pressure intensity imprint was decoded using the pressure intensity diagram, taking into account environmental parameters (temperature $-26{ }^{\circ} \mathrm{C}$, air humidity - $58 \%$ ).

Conformity of torque value of the stud, tightened with a torque wrench, to the force of studs tightening $Q 0$ evaluated by the value of membrane stresses in the stud, determined by numerical simulation and analytically - by the method of calculation of detachable joints, given in [9, 10, 11].

The results of numerical stress simulation in a stud under loading by rated force of tightening $Q 0$ are shown in Figure 12. The membrane tensile stresses in the stud corresponding to the rated force of tightening $\mathrm{Q} 0=0.1466 \mathrm{MN}$ are $(\sigma)_{m w}=192.1 \mathrm{MPa}$.

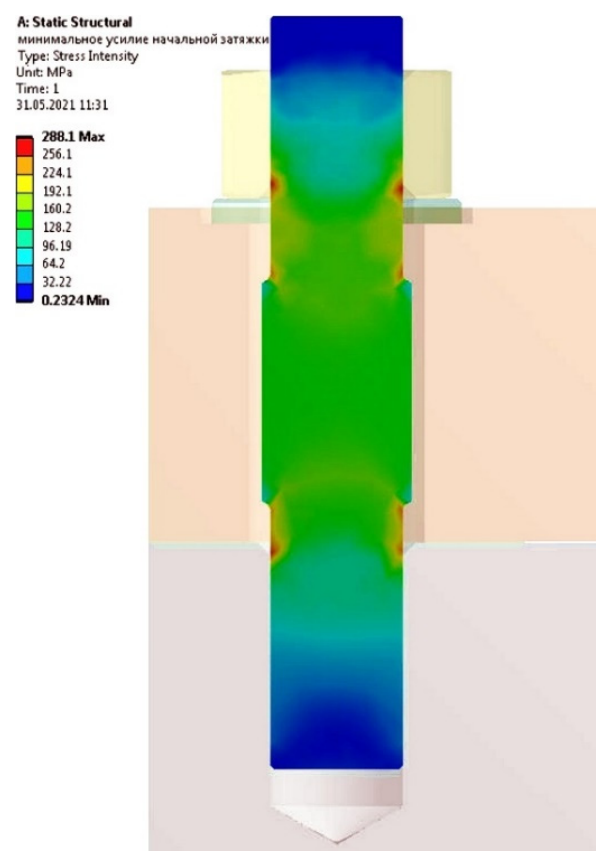

Fig. 12. Results of numerical simulation of stresses in a stud under loading by rated force of tightening $Q 0, \mathrm{MPa}$ 
According to the methodology developed for the calculation of detachable joints, the initial force of studs tightening Q0 corresponds to the torque, the value of which is defined as follow:

$$
M_{k l}=\xi_{1} \cdot F_{0 w} \cdot d_{w n} / z
$$

where $\xi_{1}=\left\{\begin{array}{c}0.2 \text { is for dry joint thread } \\ \text { according to [9], } \\ 0.37 \text { is for dry joint thread } \\ \text { according to [10] }\end{array}\right\}-$ friction ratio in the thread;

$$
F_{0_{w}}=Q 0=0.14663 \mathrm{MN} \text { was determined by }
$$
the method given in [9, 10];

$d_{w n}=0.036 \mathrm{~m}$ is the external thread diameter of the stud M36;

$z=1$ is the number of studs.

In addition, an option of determining the friction ratio by the method given in [11] is considered

$$
\xi_{1}=0.16 \cdot P+0.5 \cdot f_{p}+f_{t} \cdot D_{p r},
$$

where $\quad P=0.004 \mathrm{~m}$ is the pitch of thread;

$f_{p}=0.18$ and $f_{t}=0.16$ are the friction ratios in the thread and at the nut end face according to [11], respectively;

$$
D_{p r}=1 / 3 \cdot\left(D^{3}-d_{0}^{3}\right) /\left(D^{2}-d_{0}^{2}\right)=0.0239 \mathrm{~m} \text { is }
$$

equivalent diameter of friction;

$D=0.053 \mathrm{~m}$ is outside diameter of the nut bearing face;

$d_{0}=0.042 \mathrm{~m}$ is a diameter of hole for the stud M36 made in upper casing half.

From the given values of friction ratios which are recommended for determining the torque in $[9,10,11]$, ratio $\xi_{1}=0.2$ was taken in the calculation, as in this case the stresses determined analytically match the stresses obtained in the numerical simulation (Figure 12).

Table 5 shows the membrane stresses in the stud, determined analytically and by numerical simulation.

Table 5. Results of Membrane Stresses in the Stud, Determined Analytically and by Numerical Simulation

\begin{tabular}{|c|c|c|c|}
\hline $\begin{array}{c}\text { Description } \\
\text { parameter }\end{array}$ & $\begin{array}{c}\text { Analytical } \\
\text { calculation }\end{array}$ & $\begin{array}{c}\text { Numerical } \\
\text { calculation }\end{array}$ & $\begin{array}{c}\text { Relative } \\
\text { accuracy, } \\
\delta, \%\end{array}$ \\
\hline $\begin{array}{c}\text { Rated force of } \\
\text { studs tighten- } \\
\text { ing Q0, MN }\end{array}$ & 0.1466 & 0.1466 & - \\
\hline $\begin{array}{c}\text { Torque } M K L, \\
\text { MN·m (kgf·m) }\end{array}$ & $\begin{array}{c}0.00106 \\
(107.6)\end{array}$ & - & - \\
\hline $\begin{array}{c}\text { Membrane } \\
\text { stresses }(\sigma)_{m w}, \\
\text { corresponding to } \\
\text { the force of studs } \\
\text { tightening, MPa }\end{array}$ & 186.1 & 192.1 & 3.1 \\
\hline
\end{tabular}

During the tests, after placing the Prescale Type MS film on the joint, the flange joint is tightened with the design torque and held under the load for 5 minutes. After disassembly of the flange joint, red imprints are clearly visible on the film, the color density of which corresponds to the value of the pressure intensity. The results of tests are shown in Figure 13.

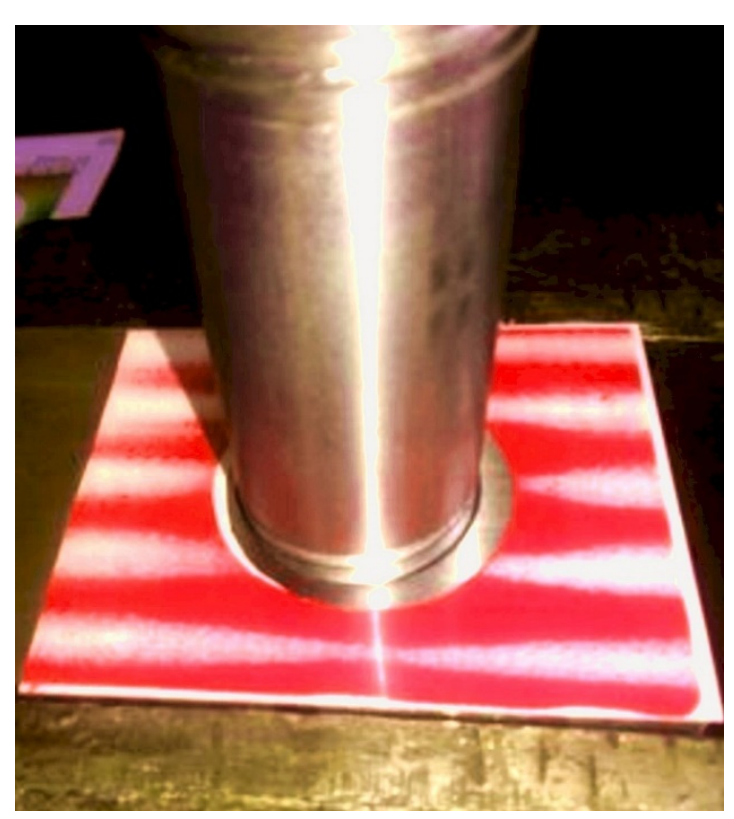

Fig. 13. Test result after loading with torque MKL

During loading of the flange model, the initial force of tightening Q0 corresponds to the torque $\mathrm{MKL}=0.00106 \mathrm{MN} \cdot \mathrm{m}(107.6 \mathrm{kgf} \cdot \mathrm{m})$.

The pressure intensity increases around a main joint stud hole, and when coming close to the external boundary of the flange. The stripes of lower intensity can be explained by the quality of machining of the contacting surfaces samples by the milling cutter.

It can be observed that the pressure intensity can be seen to change also in the normal direction to the stripes the red prints become less intense. A bright area means that the pressure intensity in these area is significantly lower.

To conclude the experiment, using the pressure intensity diagram (Figure 14), the scanned prints of the color intensity distribution on the film (Figure 15) are decoded.

Comparison of the experiment results obtained on the specimen of flange fragment (Figure 15) and the numerical results obtained on the model of flange fragment (Figure 7) shows a good agreement. The comparative results are shown in Table 6 . The relative accuracy of the results $\delta, \%$, is $5-22 \%$.

According to the results of the comparative analysis of the experiment and the numerical calculation given in Table 6, it should be noted that for the majority of reference zones - from the external contour to the tie bolt - a good coincidence of the specified and experimental values of the pressure intensity is obtained. 
Table 6. Comparative Analysis of the Experimental Results on Specimens of Flange Fragment and Numerical Results on the Flange Fragment Model Under Loading by the Rated Force of Tightening Q0

\begin{tabular}{|l|c|c|c|}
\hline $\begin{array}{c}\text { Reference zones of pressure intensity dis- } \\
\text { tribution } \\
\text { on the joint }\end{array}$ & $\begin{array}{c}\text { Numerical results on the joint } \\
\text { model of the flange fragment } \\
\text { (none film), MPa }\end{array}$ & $\begin{array}{c}\text { Experimental results } \\
\text { on the joint of specimen } \\
\text { of flange fragment, MPa }\end{array}$ & $\begin{array}{c}\delta \text { Relative accuracy } \\
\text { of analysis results in the ref- } \\
\text { erence zones on joints, \% }\end{array}$ \\
\hline $\begin{array}{l}\text { No. } 1 \text { - zone of the external contour } \\
\text { of the flange }\end{array}$ & $23.6-24.9$ & $25-30$ & $15.3-0.4$ \\
\hline No. 2 - between the 1st and 3rd zones & $24.4-28.9$ & $30-50$ & $2.4-3.6$ \\
\hline No. 3 - outer side of the stud hole & $25.4-56.2$ & $35-50$ & $15.3-11.0$ \\
\hline No. 4 - along the perimeter of the studs & $27.2-53.5$ & $25-50$ & $22.2-6.5$ \\
\hline No. 5 - outer side of the stud hole & $20.2-50.1$ & $15-25$ & $19.2-0.1$ \\
\hline No.6 - between the 5th and 7th zones & $14.3-17.9$ & $10-20$ & $4.7-28.4$ \\
\hline No. 7 - between 6th and 8th zones & $9.1-10.8$ & - & $9-46$ \\
\hline $\begin{array}{l}\text { No. } 8 \text { - zone of the inner contour } \\
\text { of the flange (none film) }\end{array}$ & $3.3-3.8$ & & - \\
\hline
\end{tabular}

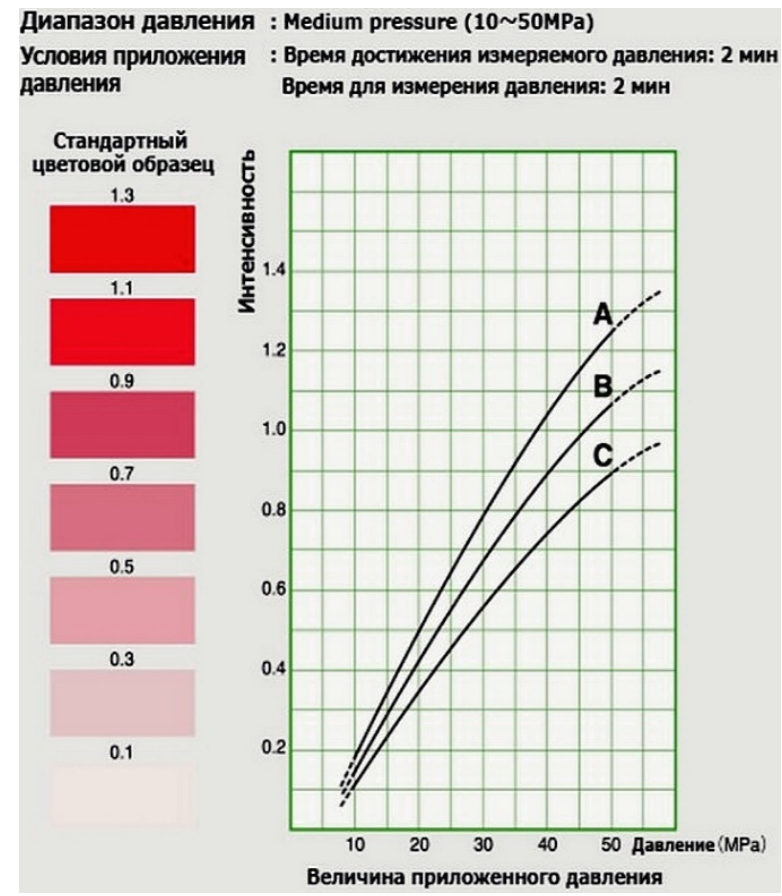

Fig. 14. Pressure intensity diagram for MS film (at medium pressure)

However, from zones 5 to 7 , the relative accuracy of the results begins to increase, achieving a peak value $\delta=46 \%$ in the $7^{\text {th }}$ zone. The explanation for this is that $9070 \mathrm{~mm}$ MS film samples were used in the experiment, whereas the size ranges of the entire joint area are 111.570 $\mathrm{mm}$. Thus, there was a load transfer from the 8th zone of $21.570 \mathrm{~mm}$, where there is no film, to the adjacent to it zones.

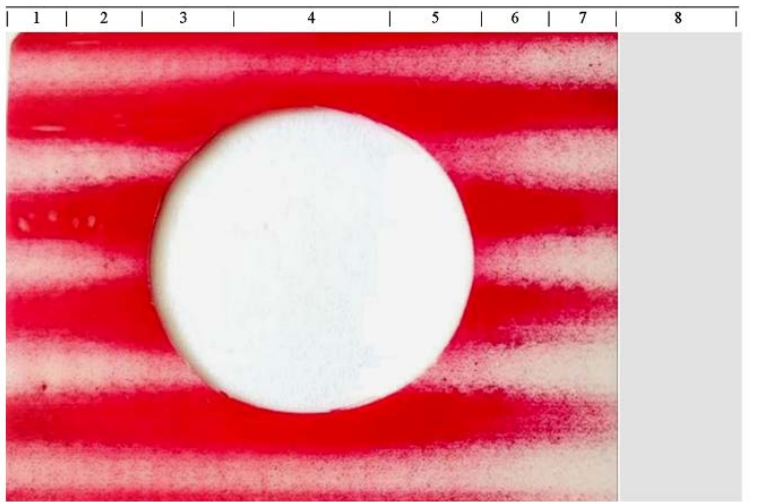

Fig. 15. Distribution of the pressure intensity in the reference zones on the contacting surfaces of the specimen of flange fragment caused by rated force of tightening $Q 0$

The edge effect is also clearly visible in Figure 8 and Figure 9, which show the results of pressure intensity calculations for flange fragment models with a film on the joint of dimensions $111.570 \mathrm{~mm}$ and $9070 \mathrm{~mm}$, respectively.

The relative accuracy of the pressure intensity results in the 7th zone is $\delta=52-54 \%$, which is comparable with the relative accuracy of the experiment results and numerical calculations, which is $\delta=46 \%$.

\section{Conclusions}

In order to verify the obtained results performed on mathematical models, an experiment was conducted to determine the pressure intensity on the contacting surfaces of 
the specimen of flange fragment of upper casing half and lower casing half.

Comparison of the results analysis of the contact problem on the finite-element models on the joint of flange fragment and on the area of the axial joint located in the discharge chamber area of the pump casing shows a good coincidence of the results. The relative accuracy $\delta$, \%, of the pressure distribution on the joint in the reference zones is rated at $4-18 \%$.
Comparison of the experiment results obtained on the specimen of flange fragment and the numerical results obtained on the model of flange fragment shows a good agreement of the results. The relative accuracy of pressure distribution on the joint in the reference zones $\delta, \%$, is $5-22 \%$.

Accordingly, the experiment results confirm the validity of the results on the mathematical models using ANSYS software package.

\title{
References
}

[1] A.S. Kostronoy et al., “Optimizatsiya massy korpusa tsentrobezhnogo nasosa spiral'nogo tipa s gorizontalnym razyemom varirovaniyem kharakteristik zhestkosti konstruktivnykh elementov [Mass Optimization of Centrifugal Pump Volute Casing with Axial Split by Variation of Design Components Stiffness]”, Promyshlennaya Gidravlika i Pnevmatika, Vinnitsa, No. 2 (56), 2017.

[2] V.F. Khvorost, A.S. Grytsenko and S.V. Syzonenko. "Otsenka vliyaniya nagruzok, deystvuyushchikh na patrubki, na ekspluatatsionnyye pokazateli magistralnykh neftyanykh nasosov [Assessment of the Influence of loads acting on the nozzles on the performance indicators of main oil pumps]”, Kompressornoye i Energeticheskoye Mashinostroyeniye, No. 2 (48), 2017.

[3] Plenka Prescale, fiksiruyushchaya raspredeleniye udelnogo davleniya v razemnykh soyedineniyakh (2017) [Online]. Available: https://www.fujifilm.eu/ru/produkty/promyshlennye-produkty/plenka-prescale-dlja-izmerenija-raspredelenija-davlenija/plenka-prescale-dlja-ocenki-raspredelenija-okazyvaemogo-davlenija

[4] N.D. Chainov, et al., Raschetnoye i eksperimentalnoye opredeleniye lokalnykh velichin kontaktnogo davleniya $v$ sopryazhenii detaley porshnya sredneoborotnogo dizelya tipa [An Experimental Measurement and Numerical Calculation of Contact Pressure in a Composite Piston of a Mid-speed Diesel Engine], Moscow, Bauman Moscow State Technical University, 2017.

[5] ANSYS 14.5, license agreement 1066541.

[6] SolidWorks 2012, license agreement 1-12403719039.

[7] GOST 26159-84. Sosudy i apparaty chugunnyye. Normy i metody rascheta na prochnost. Obshchiye trebovaniya. [Cast Iron Vessels and Apparatus. Norms and Methods of Strength Calculation. General Requirements], Moscow, 1985.

[8] DSTU 3925-99. Chavun z kulyastym hrafitom dlya vylyvkiv [Cast Iron with Spherical Graphite for Castings], Kyiv, State Standard of Ukraine, 2000.

[9] I.A. Bierger et al., Strength Calculation of Machine Parts: Handbook, Moscow, Mashinostroyeniye, 1993.

[10] PNAE G-7-002-86. Normy rascheta na prochnost oborudovaniya i truboprovodov atomnyih energeticheskih ustanovok [Strength Analysis Standards for Nuclear Power Unit Equipment and Pipelines], Gosatomenergonadzor SSSR, Energoatomizdat, Moscow, Russia, 1989.

[11] G.B. Iosilevich. Detali mashin: Uchebnik dlya studentov mashinostroitelnykh spetsialnostey vuzov. [Machine Parts. Tutorial For Students of Engineering Specialities], Moscow, Mashinostroyeniye, 1988.

\section{Исследование интенсивности давления в разъемных соединениях насосов типа D - экспериментально и численными методами расчета}

\author{
А.А. Руденко, В.Н. Зубко, В.Ф. Хворост, А.А. Лысенко
}

Аннотация. Объектом исследований является иентробежный одноступенчатый насос двустороннего входа спирального типа с горизонтальным разъемом корпуса.

Проблема. В прочессе проектирования решается проблема герметичности горизонтального разъема корпуса насоса, находящегося под действием высокого давления и температуры. При исследовании герметичности горизонтального разъема используются численные методы расчета, позволяющче оценивать интенсивность давления на контактируюших поверхностях. Разъемное соединение, находящееся под действием внешней нагрузки, удовлетворяет критериям герметичности, если интенсивность давления на уплотняемых поверхностях выше значений удельного давления, установленных нормативными документами. Однако отсутствие возможности экспериментального определения интенсивности давления на контактируюших поверхностях не позволяло до настоящего времени оченить точность результатов, получаемых численными методами расчета.

Цель исследования. С иелью верификации численных результатов, полученных на математических моделях, был проведен эксперимент с использованием специальной пленки Prescale, фиксирующей величину контактного давления на разъеме образца модели фрагмента фланиа. По результатам эксперимента проведен анализ распределения интенсивности давления. 
Методика реализации. Для проведения эксперимента была разработана методика определения интенсивности давления на контактирующих поверхностях по предложенной схеме образиа фрагмента фланца.

Результаты исследования. Сопоставительный анализ результатов решения контактной задачи на конечно-элементных моделях фрагмента фланца и участка разъема корпуса насоса в области напорной полости показал хорошее совпадение результатов. Анализ результатов, полученных экспериментально на образце фрагмента фланца, и результатов численного расчета на модели фрагмента фланца также показал хорошее совпадение.

Выводы. Таким образом, получено экспериментальное подтверждение результатов расчета интенсивности давления в разъемных соединениях на математических моделях.

Ключевые слова: интенсивность давления, тензометрическая пленка, главный разъем, локальная зона, образеи фрагмента фланщев, характерная зона, численное моделирование напряжений, мембранные напряжения, экспериментальное моделирование, верификация результатов.

\section{Дослідження інтенсивності тиску у роз'смних з’єднаннях насосів типу D - експериментально та чисельними методами розрахунку}

\section{А.А. Руденко, В.М. Зубко, В.Ф. Хворост, А.А. Лисенко}

Анотація. Об'єктом дослідження є відиентровий одноступеневий насос двостороннього входу спірального типу з горизонтальним роз'ємом корпуса.

Проблема. У процесі проектування насосів вирішується проблема герметичності горизонтального роз'єму корпуса насоса, що знаходиться під дією високого тиску та температури. При дослідженні герметичності горизонтального роз'єму використовуються чисельні методи розрахунку, щьо дозволяють оиінювати інтенсивність тиску на поверхнях, щчо контактують. Роз'ємне з'єднання, щу знаходиться під дією зовнішнього навантаження, задовольняє критеріям герметичності, якщо інтенсивність тиску на ущільнювальних поверхнях буде вище значень питомого тиску, встановлених нормативними документами. Однак відсутність можливості експериментального визначення інтенсивності тиску на поверхнях, щуо контактують, не дозволяло до теперішнього часу оцінити точність результатів, отриманих за допомогою чисельних методів розрахунку.

Мета дослідження. 3 метою верифікації чисельних результатів, отриманих на математичних моделях, було проведено експеримент із використанням спеціальної плівки Prescale, яка фіксує величину контактного тиску на роз'ємі зразка моделі фрагмента флания. За результатами експерименту проведено аналіз розподілу інтенсивності тиску.

Методика реалізації. Для проведення експерименту була розроблена методика визначення інтенсивності тиску на контактуючих поверхнях за запропонованою схемою зразка фрагмента флания.

Результати дослідження. Порівняльний аналіз результатів вирімення контактної задачі на кінцево-елементних моделях фрагмента флания та ділянки роз'єму корпусу насоса в області напірної порожнини показав гарний збіг результатів. Аналіз результатів, отриманих експериментально на зразку фрагмента фланця, і результатів чисельного розрахунку моделі фрагмента флания також показав хороший збіг.

Висновок. Таким чином отримано експериментальне підтвердження результатів розрахунку інтенсивності тиску в роз'ємних з'єднаннях на математичних моделях.

Ключові слова: інтенсивність тиску, тензометрична плівка, головний роз'єм, локальна зона, зразок фрагмента фланців, характерна зона, чисельне моделювання напружень, мембранні напруження, експериментальне моделювання, верифікація результатів. 